\title{
Hot Beverages at Quick Service Restaurant (QSR) Drive-Thru Windows
}

\author{
Carl P. Borchgrevink and Michael P. Sciarini \\ Michigan State University \\ Alex M. Susskind \\ Cornell University
}

\begin{abstract}
$\underline{\text { Author Note }}$
Address correspondence to Marc Stierand, Centre for Hospitality and Tourism Research (CHTR), Victoria University, 12 Geelong Road, Footscray, Melbourne VIC 8001, Australia. E-mail: marc.stierand@vu.edu.au
\end{abstract}


The Liebeck hot coffee case is discussed, showing that the court's decision was not whimsical, but predicated on the knowledge and behaviour of McDonald's as represented and displayed by their employees and agents. Subsequent research establishing consumer preferred temperatures for consuming hot beverages is reviewed, as is the literature considering that such temperatures are above medical literature thresholds for injuries, yet not causing injuries. Past and current quick service restaurant (QSR) drive-thru window practices regarding hot beverage service temperatures and warnings are established and examined. Finally, circumstances and conditions under which QSR management need to practice due diligence in providing for their customers are addressed. 


\section{Hot Beverages at Quick Service Restaurant (QSR) Drive-Thru Windows}

In 1994 a jury decision to award Ms Stella Liebeck nearly \$3 million from McDonald's created quite an uproar within the hospitality industry and among the general public. While the judge presiding over the case later reduced the verdict and a final settlement was reached outside of the courts, the case still has significant implications for hospitality business operators and the public at large.

Many have heard of the 1994 case in which Ms Stella Liebeck was awarded \$2.9 million in a combination of compensatory and punitive damages for burning herself with coffee received at a McDonald's drive-thru window. Some of the outrage centred on the notion that coffee is supposed to be hot, and that Ms Liebeck should have taken greater care not to spill her coffee. Many believe that she had the cup between her legs and was driving at the time of the spill. Some believe that the case was totally frivolous, and that it represented an out-of-control litigious society. A mock prize, The Stella Award ('StellaAwards.com', 2006), has even been named after Stella Liebeck's case. This award is given each year to the case that is deemed the most frivolous. Others believe the case was helpful and instrumental in encouraging safer hospitality practices, as well as safer hot beverage cups and lids. The discussion and controversy continues to this date (see, e.g., Fleischer-Black, 2004; Greenbaum, 2005; Lane, 2006; Off the Kuff, 2002; Olson \& Frank, 2006; 'The Real Facts', 2006).

\section{The Facts of the Liebeck Case}

The most pertinent facts of this case as reported by the Wall Street Journal (Gerlin, 1994) and the New York Times (Shaw, 1994) follow. The law firm hired to defend McDonald's in the 
Stella Liebeck case sent a law student to measure coffee temperatures at other establishments and found that none of the cups of coffee at other restaurants were as hot as the coffee served by McDonald's. The closest cup was approximately $20^{\circ} \mathrm{F}\left(11^{\circ} \mathrm{C}\right)$ below the temperature at which McDonald's apparently was serving coffee. The temperature McDonald's is cited as using is about $180^{\circ} \mathrm{F}\left(82^{\circ} \mathrm{C}\right)$. Prior to trial the opposing lawyers received the McDonald's operating manual. It stipulated that coffee should be brewed at a temperature ranging from $195^{\circ} \mathrm{F}\left(90.6^{\circ} \mathrm{C}\right)$ to $205^{\circ} \mathrm{F}\left(96.1^{\circ} \mathrm{C}\right)$, and held at the range of $180^{\circ} \mathrm{F}\left(82.2^{\circ} \mathrm{C}\right)$ to $190^{\circ} \mathrm{F}\left(87.8^{\circ} \mathrm{C}\right)$ for optimal taste. Ms Liebeck was a passenger in a car, and the car was parked at the time of the spill. She had ordered a cup of coffee at the drive-thru and it had been served with sugar and cream on the side. When Ms Liebeck attempted to remove the lid in order to add the cream and sugar, she held the cup between her legs for stability, but wound up spilling coffee on her groin, inner thighs and buttocks. Her burns were severe and she spent 7 days in the hospital during which she received skin grafts among other treatments. In her suit, Ms Liebeck claimed that the coffee was a defective product due to the high serving temperature of the coffee. It should be noted, however, that Ms Liebeck had initially not intended to sue McDonald's, but simply requested compensation for her pain and coverage of her medical bills. McDonald's claimed they were not liable for Ms Liebeck’s pain and injury, but offered her $\$ 800$ nonetheless.

During the trial it became known that McDonald's was well aware of the injury potential of their coffee, as they had received 700 or more reports of coffee burns ranging up to third degree burns, and that they had settled many of these claims for substantial amounts of money. One such claim was settled for about $\$ 230,000$. In the Liebeck case, however, McDonald's declined to settle, and rejected several offers including a recommendation by a court-mandated mediator to settle at $\$ 225,000$. 
During the trial a scientist retained by McDonald's suggested that the serving temperature of coffee should be a nonissue as any coffee higher than $130^{\circ} \mathrm{F}\left(54.4^{\circ} \mathrm{C}\right)$ could produce third degree burns. A doctor testifying on Ms Liebeck's behalf suggested that lowering the serving temperature to $160^{\circ} \mathrm{F}\left(71.1^{\circ} \mathrm{C}\right)$ would make a significant difference, as $190^{\circ} \mathrm{F}\left(87.8^{\circ} \mathrm{C}\right)$ coffee could cause a third degree burn in about three seconds, while it would take 12 to 15 seconds at $180^{\circ} \mathrm{F}\left(82.2^{\circ} \mathrm{C}\right)$ and about 20 seconds at $160^{\circ} \mathrm{F}\left(71.1^{\circ} \mathrm{C}\right)$.

Much damage was done to McDonald's case by their own defensive efforts. A McDonald executive confirmed on the witness stand that they indeed knew that their coffee sometimes caused serious burns, but that they saw no reason to lower their coffee temperature standards, consult a burn expert, or even warn their customers. The executive noted further that they realized that most people would not expect McDonald's coffee to be able to cause such serious burns as it indeed could cause. A human factors expert testified that the number of coffee burns that occurred with McDonald's coffee was statistically insignificant considering the numbers of cups of coffee that McDonald's serves. The jurors were given the impression that McDonald's did not care about the wellbeing of their customers, but simply considered them numbers, and insignificant numbers at that!

The jurors felt that Ms Liebeck had to accept some responsibility and assigned her 20\% of the fault and reduced a $\$ 200,000$ damage award to $\$ 160,000$. In terms of punitive damages, they settled on a value equivalent to 2 days of McDonald's coffee sales. During the trial, Ms Liebeck's attorney, Mr. Reed Morgan, estimated that McDonald's' company-wide coffee sales averaged \$1.35 million per day. Thus they awarded her \$2.7 million. 


\section{Consumer-Preferred Temperatures}

The verdict caused quite a bit of a stir in the general media, as in the hospitality industry. Borchgrevink, Susskind and Tarras (1999) took notice of the case and the apparent disparity between the temperature the medical literature established as dangerous and the temperature the

hospitality industry suggested was appropriate for brewing and holding coffee. Specifically they noted that... it would appear that the temperatures specified as recommended temperatures by the hospitality and food science literatures for brewing and holding coffee are at odds with the medical literature's discussion of beverage temperatures that result in burns, permanent cellular damage and death. (p. 118)

That the consumption of coffee could lead to death was particularly bold, but they reported on a case (Mellen, Golle, \& Smialek, 1995) in which an individual downed a hot cup of coffee and subsequently died from the damage it caused the individual's upper aero digestive tract. It appeared that the individual, who was suffering from a mental disorder, suffered burns and swelling to such a degree that suffocation ensued. Given the person's mental state, his behaviour was apparently not noticed as aberrant until it was too late. Borchgrevink et al. (1999) decided to see whether anyone had asked consumers at what temperature they preferred to drink hot beverages. Anecdotally, most consumers suggest that they want their coffee to be 'hot', and that preference is one of the reasons the public at large were outraged at the results of the Liebeck case, and remain puzzled as to the merits of any hot beverage case. Borchgrevink et al. (1999) could not find an empirical inquiry into the temperature(s) at which consumers preferred to consume hot beverages. The only evidence they found indicating an awareness of a potential consumer- preferred consumption temperature standard was an editorial in the New York Times (January 3,1995$)$ stating that experts in a coffee burn case specified $154^{\circ} \mathrm{F}\left(67.8^{\circ} \mathrm{C}\right)$ as sip-able. 
Given the disparate temperature standards and the dearth of research, Borchgrevink et al. (1999) set out to see whether it was possible to establish a meaningful consumer-preferred coffee consumption temperature. They collected data in the United States (US) Midwest and US southeast, exposing 250 volunteer college students to seven different servings of black coffee, one cup at a time, in a randomized temperature pattern. The temperatures ranged from $135^{\circ} \mathrm{F}$ $\left(57.2^{\circ} \mathrm{C}\right)$ to $195^{\circ} \mathrm{F}\left(90.6^{\circ} \mathrm{C}\right)$ with $10^{\circ} \mathrm{F}\left(5.6^{\circ} \mathrm{C}\right)$ intervals. All subjects were given black coffee without condiments of any sort and asked to establish whether the temperature was good for immediate consumption. Their findings suggested that the ideal temperature for consumption of hot coffee lies within the $145^{\circ} \mathrm{F}-155^{\circ} \mathrm{F}\left(62.8^{\circ} \mathrm{C}-68.3^{\circ} \mathrm{C}\right)$ range with mean responses suggesting that coffee is ideally consumed in the upper part of said range. They point out that the preferred temperature is below the level recommended for brewing and holding coffee, but above thermal damage thresholds discussed by the medical literature.

Subsequent to Borchgrevink et al.'s (1999) study, several studies sponsored by the Specialty Coffee Association appeared in the literature (Lee, Carstens \& O’Mahoney, 2003; Lee \& O’Mahoney, 2002; Pipatsattayanuwong, Lee, Lau, \& O’Mahoney, 2001). These studies focused on preferred consumption temperatures, expected serving temperatures, the potential of such temperatures to cause pain or damage in the consumer's mouth, and the recording of the time lapse between the purchase of coffee and the first sip of said coffee. In sum, their findings of preferred consumption temperatures are broadly consistent with those reported by Borchgrevink et al. (1999). The specific results follow.

Pipatsattayanuwong et al. (2001) performed three experiments. In the first experiment the subjects $(\mathrm{N}=225)$ poured coffee samples from six servers containing coffee at different temperatures. They were asked to rank-order the coffees in term of consumption preference. The 
most preferred mean temperatures were $161.8^{\circ} \mathrm{F}\left(72.1^{\circ} \mathrm{C}\right)$ and $141.7^{\circ} \mathrm{F}\left(60.9^{\circ} \mathrm{C}\right)$, as most preferred and second most preferred, respectively. The second experiment was immediately subsequent, used the same subjects and servers, but introduced the type of paper-based cup used in coffee shops, rather than the polystyrene cups used in study 1 , and asked them to judge the coffee as they normally would in a coffee shop — such as by feel of the cup or sip. They were asked to rank order the cups relative to the coffee temperature that would not be a surprise if served in a coffee shop. The two most expected temperatures were $167.2^{\circ} \mathrm{F}\left(75.1^{\circ} \mathrm{C}\right)$ and $144.7^{\circ} \mathrm{F}\left(62.6^{\circ} \mathrm{C}\right)$, respectively. The least expected temperatures were the lowest temperatures offered, while the two hottest temperatures were in the middle of the range of expectation. The third experiment was an observational study in coffee shops in which subjects $(\mathrm{N}=110)$ who drank black coffee were observed and at times followed, to determine how quickly they took the first sip of their coffee. An estimate of coffee temperature at the time of the first sip was made using model cups and model pours, so as not to disrupt customers for measurements, nor alert them to their surreptitious involvement in an observational study. While 54\% took their first sip within 2 minutes, $71 \%$ had taken their first sip within 3 minutes. With time divided into 30-second intervals, the most commonly observed interval was 30 to 60 seconds. The observed delay as mode, median and mean were 54 seconds, 114 seconds, and 160 seconds ( $\mathrm{SD}=168$ seconds). The estimated temperatures ranged from $135^{\circ} \mathrm{F}$ to $183^{\circ} \mathrm{F}\left(57.2^{\circ} \mathrm{C}-83.9^{\circ} \mathrm{C}\right)$ with a mean of $168^{\circ} \mathrm{F}\left(75.5^{\circ} \mathrm{C}\right)(\mathrm{SD}=$ $9^{\circ} \mathrm{F}, 5^{\circ} \mathrm{C}$ ). While they point out that these temperatures are slightly above those of experiment 1 , they note that these first sips may simply have been initial exploratory assessments and do not necessarily reflect consumption temperatures. With consumers who used condiments they were not able to establish reasonable temperature estimates, as the amount and type of condiment and the mixing methods varied greatly. 
Lee and O'Mahoney (2002) took two slightly different approaches. Initially they allowed their subjects $(\mathrm{N}=300)$ to prepare their coffee as they normally would with cream, milk, or sugar in any combination, all or neither, and asked them to indicate when the temperature of the coffee was 'just right'. At that point they measured the temperature. They report that consumers of black coffee preferred a temperature of $142.7^{\circ} \mathrm{F}\left(61.5^{\circ} \mathrm{C}\right)$, while those who added milk, cream or sweetener to the coffee preferred a slightly cooler temperature of $138.2^{\circ} \mathrm{F}\left(59.0^{\circ} \mathrm{C}\right)$, with an overall mean of $139.6^{\circ} \mathrm{F}\left(59.8^{\circ} \mathrm{C}\right)$. In the second study $(\mathrm{N}=108)$ they only served black coffee, but served it brewed at two different strengths. The mean preferred temperature for the stronger coffee was $138.7^{\circ} \mathrm{F}\left(59.3^{\circ} \mathrm{C}\right)$ while the mean preferred temperature for the weaker coffee was $140.7^{\circ} \mathrm{F}\left(60.4^{\circ} \mathrm{C}\right)$. As part of our review we estimated a confidence interval at $\mathrm{p}=.05$ for these reported mean preferred temperatures, and found the confidence intervals to overlap, suggesting there is no statistically significant difference between the means.

Lee et al. (2003) re-emphasize that the literature above suggests that the preferred consumption temperatures of coffee reported by many people are above pain and damage thresholds in the mouth, yet people typically do not report injuries to the mouth from hot coffee. They ask whether the coffee, by the time it reaches the oral cavity, is cooler than it was in the cup. To start answering this question, they measured coffee temperatures at various points within a cup, as well as in the mouth. They reported temperature variations within a cup as high as $14.4^{\circ} \mathrm{F}\left(8.0^{\circ} \mathrm{C}\right)$ from the coolest surface area to the hottest parts. Excluding the coolest part at the surface they found a much smaller range of variation, namely $5.4^{\circ} \mathrm{F}$ to $9.0^{\circ} \mathrm{F}\left(3.0^{\circ} \mathrm{C}-5.0^{\circ} \mathrm{C}\right)$. To measure the potential temperature change from cup to oral cavity, they used as the starting point a lightly submerged temperature, rather than the cooler surface temperature. This submerged temperature is more reflective of the potential average temperature of coffee in a cup and thus 
sips - as well as a reasonable average for the cup as a whole. They found a mean temperature difference between the cup and the anterior dorsal surface of the tongue of $23.4^{\circ} \mathrm{F}\left(13.0^{\circ} \mathrm{C}\right)$. They report further that the temperatures measured in the mouth exceeded the human thermal pain threshold and were on occasion high enough to cause damage. Their subjects, however, neither reported pain nor suffered any tissue damage to their oral cavities. They suggest that the typical consumer likely sips a small bolus of coffee and swallows it rather quickly, or agitates the coffee bolus in the mouth so that hot liquid does not linger on any surface, thus avoiding any thermal pain or tissue damage. They suggest further that Borchgrevink et al.'s (1999) bold statement would only apply if coffee is held in the mouth for an extended period of time, or otherwise not consumed as intended, such as when a larger than normal bolus is entered into the oral cavity, or if it is spilled and the spill is held in place by clothing long enough to elicit burns.

\section{Coffee-Temperatures at the Drive-Thru}

Following the Liebeck case, Rutherford (1998) argued that food service operators cannot and should not ignore the potential risk to consumers - particularly children and elderly adults — posed by hot beverages being served through drive-thru windows. He suggested that a reasonable response from food service operators would be to lower the temperature of the beverages, or to provide verbal warning when serving such coffee. The verbal warning is important because, as Rutherford (1998) mentioned, one of the issues in the Liebeck case was that Ms Liebeck was not warned of the coffee's temperature. Lowering the serving temperature would be an easy remedial step. The fact that McDonald's had not lowered the serving temperature in the face of the 700 or more reports of coffee burns led the judge in the Liebeck case to characterize McDonald's conduct as 'willful, wanton, reckless and callous' (McGreevy, 
1994). Rutherford (1998) set out to establish whether quick service restaurants (QSRs) had reduced the temperature of the coffee they serve and whether they provided a verbal warning at the time of service. The assessment was done in 1996 and 1997, several years after the Liebeck case and should have provided QSRs with ample time to implement any desired system wide procedural changes.

Rutherford (1998) recruited 21 junior and senior students, equipped them with calibrated thermometers, and trained them in data collection. Specifically, he had them purchase coffee at the drive-thru window of local QSRs over a 2-month period and measure the temperature of the hot beverages through the lid immediately upon receipt. They were also instructed to note any verbal or written warnings they received regarding the temperature of the beverages.

The findings (Rutherford, 1998) indicated that the QSRs had in fact reduced the mean serving temperature for drive thru coffees. They found an average serving temperature of $167.1^{\circ} \mathrm{F}\left(75^{\circ} \mathrm{C}\right)$, which was much lower than the presumed 'standard' as specified by the Liebeck case temperature estimate of about $180^{\circ} \mathrm{F}\left(82^{\circ} \mathrm{C}\right)$. They reported further that the McDonalds' restaurants included in the sample had a significantly lower mean serving temperature $\left(165^{\circ} \mathrm{F} / 73.9^{\circ} \mathrm{C}\right)$ than other QSRs in the study. Rutherford (1998) emphasised that each and every one of the coffee samples obtained were hot enough to result in serious injury if spilled on a person, particularly if the person was under 5 years of age or older than 65. Rutherford (1998) also reported that $19.2 \%$ of the QSRs provided a verbal warning about the temperature of the coffee as it was served at the drive-thru window and that $47.9 \%$ of the QSRs included a written warning on the coffee container. 


\section{A 'Fresh' Coffee Sample}

Given the continued discussion of the Liebeck case and hot beverage temperatures in general, and the length of time that has passed since Rutherford's (1998) work, the authors decided it would be useful to assess current coffee service temperatures and current approaches to warnings regarding the risk of burns and scalds.

\section{Methods}

We set out to replicate Rutherford's (1998) work during the months of October and November, 2006. The authors and a handful of graduate students were issued Taylor $6092 \mathrm{~N}-1$ Standard Grade 1" Dial Bi-Therm® instant-read thermometers with a 1-point calibration for \pm $1 \%$ at dial midpoint with a degree division of 2 . The thermometers were calibrated according to the manufacturer's instructions.

Coffee samples were obtained at QSRs with drive-thru windows in the central parts of Michigan and in the Fingerlakes region of New York, representing rural, suburban and small urban communities. The drive-thru window was chosen as the point-of-purchase, as in-store service of coffee across the counter does not include the same environmental variables and safety concerns as service of coffee through the drive-thru window. At a minimum, in-store purchases are different in that tables and countertops exists at which the hot beverages can be tended. Small cups of black coffee were ordered at the drive-thru and, as soon as the coffee was received, the temperature of the coffee was measured by piercing the thermometer through the lid of the cup so as not to allow much heat to dissipate, and to maintain researcher safety — most coffee spills associated with drive-thru windows have taken place during attempts at removing the coffee lids. 
A total of 164 samples were obtained. This was considered an adequate sample size to detect medium effect size mean differences at $p=.05$ (Cohen, 1988). Upon measurement, the temperature was noted along with the name and location of the establishment, the date and time of day and any other noticeable occurrence.

\section{Results}

\section{Warnings}

Nearly all of samples $(97.6 \%)$ contained a written warning. This is a large increase compared to the $47.9 \%$ reported by Rutherford (1998). Only four samples came without a written warning. These occurred during four of five different visits to the same independent establishment. Most of the coffees had written warnings on the cups and on lids. The lid warnings were generally embossed or indented, while the cups contained warnings printed on the side of the cup. With the exception of the bilingual nature of the warnings on McDonald's cups and the use of colour, bold type and a pictorial in Wendy's warnings, these warnings seem to have been developed without the aid and consideration of existing research on warning design (see, e.g., Adams \& Edworthy, 1995; Edworthy \& Adams, 1996; Silver \& Braun, 1993; Wogalter, Conzola, \& Smith-Jackson, 2002). The warnings were hard to spot and read, particularly while seated in the interior of a vehicle as in the case of drive-thru purchases. Warnings were typically in the same colour as the cup or lid, in a font that was hard to read or even notice due to size, style, emphasis or angle. Cab lights (interior car lights) and reading glasses were typically required to find and read the warnings. Some warnings were even covered by heat-protective sleeves provided with the cup! Those most vulnerable to burns, the very young and the elderly, would have the hardest time noticing, reading and responding to these 
warnings. These warnings appear to have been added to the cups and lids from a compliance perspective, rather than from the perspective of customer concern and safety.

There has also been a drastic change in the percentage of verbal warnings. Rutherford (1998) reported that $19.2 \%$ issued a verbal warning. In our study we only received verbal warnings during $2.5 \%$ of the coffee purchases.

\section{Bagged Coffee}

At one particular QSR location, the container of hot coffee was twice handed through the drive-thru window in a small paper sack. This approach to delivery was challenging for the researcher, as it was hard to remove the cup from the bag without spilling coffee. It is not hard to imagine the hazards involved in serving 'bagged coffee', particularly if the recipient or driver of the vehicle has limited dexterity, as may be the case for older patrons, or if the driver attempts to move out of the drive-thru lane while handling the bag or its contents. For the sake of research consistency, we ordered black coffee. If a customer were to order coffee with cream or sugar and the condiments came in the bag as well, cluttering the cup, this would further exacerbate the difficulty of extracting the coffee safely from the bag, adding additional risk and concern.

\section{Coffee Temperatures}

The mean temperature for coffee immediately upon service was $164.5^{\circ} \mathrm{F}\left(73.6^{\circ} \mathrm{C}\right)$ with a median temperature of $166^{\circ} \mathrm{F}\left(74.4^{\circ} \mathrm{C}\right)$ and a mode of $160^{\circ} \mathrm{F}\left(71.1^{\circ} \mathrm{C}\right)$. The range of obtained coffee temperatures was $72^{\circ} \mathrm{F}\left(40^{\circ} \mathrm{C}\right)$, ranging from $115^{\circ} \mathrm{F}\left(46.1^{\circ} \mathrm{C}\right)$ to $187^{\circ} \mathrm{F}\left(86.1^{\circ} \mathrm{C}\right)$. The standard deviation was 12.59 . While the temperature distribution appears approximately normal (refer to Figure 1) a Kolmogorov-Smirnov test $(\mathrm{Z}=1.39, \mathrm{p}=.04)$ suggested there is slight 
deviation from a normal distribution. This is consistent with Rutherford's (1998) findings and is not a concern given the statistical

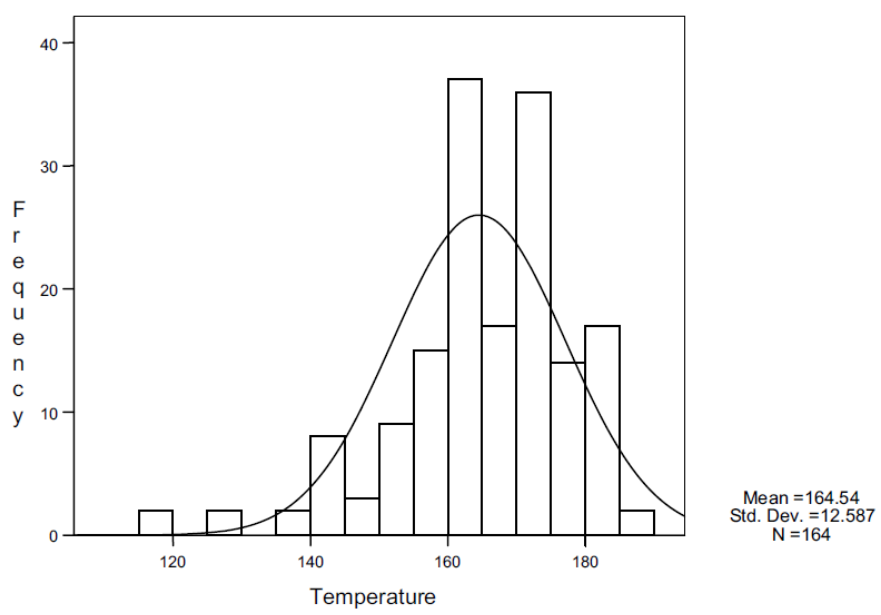

Figure 1

Histogram of obtained temperatures with superimposed normal curve.

analysis performed. Table 1 contains the coffee temperatures by establishment. The 'other' category includes A\&W, Arby's, Buzz, College Town Bagels (CTB), and Culver's. The mean temperature was highest at Burger King, followed by KFC, McDonald's, Wendy's, Steak \& Shake, and Other. Applying a 95\% confidence interval to the means, Burger King's confidence interval overlap with KFC's, but with none of the other QSRs, while KFC's overlaps with the other QSRs. Burger King's temperature was not only the highest, but was significantly $(\mathrm{p}=.05)$ higher than all other QSR temperatures excepting KFC's. The mean temperatures obtained at McDonald's, Wendy's, Steak \& Shake another were not significantly $(\mathrm{p}=.05)$ different from one another, nor from that obtained at $\mathrm{KFC}(\mathrm{p}=.05)$.

While the mean temperature in our sample, $164.5^{\circ} \mathrm{F}\left(73.6^{\circ} \mathrm{C}\right)$, was similar to that reported by Rutherford $(1998)$, that is $165^{\circ} \mathrm{F}\left(73.9^{\circ} \mathrm{C}\right)$, we note that the upper end of four of the six reported temperature ranges were on or above the service temperature cited in the Liebeck case. 


\section{Implications for Industry Practice}

While it appears that the temperatures of coffees served through the drive-thru windows at QSRs have a mean temperature lower than that observed in the Liebeck case and consistent with the temperature observed by Rutherford (1998), the mean serving temperatures are still capable of causing severe burns. The temperatures at the upper end of the range are clearly hazardous as it would only take 12 to 15 seconds of contact to cause third degree burns at this temperature. The need for service vigilance has not waned, especially at the drive-thru window where the risk of burns is greater than in other food service settings. Warning the customer is still requisite and consistent with responsible business practices! This is particularly critical when the QSR moves the final production steps to the environment of the customer's car, as in the case of having customers remove lids, crack lids, or adjust openings in the lid to add condiments to the coffee or perhaps add a teabag to scalding water. If the final steps of preparing a hot beverage are left for customers to perform, then the food service establishment needs to ensure that they have a safe work surface upon which to complete these final production steps. We noticed that McDonald's has started to offer to finish the coffee for the customer, by adding the appropriate condiments for them before the beverage is passed through the window. This greatly reduces the risk of scalding by removing the customer from involvement in the production of the purchased product. 


\section{Table 1}

Coffee Temperatures by Establishment

\begin{tabular}{|c|c|c|c|c|}
\hline Establishment & Mean temperature & Temperature range & $N$ & $S D$ \\
\hline McDonald's & $\begin{array}{l}164.5^{\circ} \mathrm{F} \\
73.6^{\circ} \mathrm{C}\end{array}$ & $\begin{array}{c}142^{\circ} \mathrm{F}-186^{\circ} \mathrm{F} \\
61.1^{\circ} \mathrm{C}-85.6^{\circ} \mathrm{C}\end{array}$ & 49 & 9.6 \\
\hline Burger King & $\begin{array}{l}175.8^{\circ} \mathrm{F} \\
79.9^{\circ} \mathrm{C}\end{array}$ & $\begin{array}{c}156^{\circ} \mathrm{F}-187^{\circ} \mathrm{F} \\
68.9^{\circ} \mathrm{C}-86.1^{\circ} \mathrm{C}\end{array}$ & 34 & 6.0 \\
\hline Wendy's & $\begin{array}{l}163.3^{\circ} \mathrm{F} \\
72.9^{\circ} \mathrm{C}\end{array}$ & $\begin{array}{c}150^{\circ} \mathrm{F}-174^{\circ} \mathrm{F} \\
65.6^{\circ} \mathrm{C}-78.9^{\circ} \mathrm{C}\end{array}$ & 24 & 6.7 \\
\hline $\mathrm{KFC}$ & $\begin{array}{l}165.5^{\circ} \mathrm{F} \\
74.2^{\circ} \mathrm{C}\end{array}$ & $\begin{array}{c}138^{\circ} \mathrm{F}-182^{\circ} \mathrm{F} \\
58.9^{\circ} \mathrm{C}-83.3^{\circ} \mathrm{C}\end{array}$ & 11 & 12.6 \\
\hline Steak \& Shake & $\begin{array}{l}157.8^{\circ} \mathrm{F} \\
69.9^{\circ} \mathrm{C}\end{array}$ & $\begin{array}{c}144^{\circ} \mathrm{F}-170^{\circ} \mathrm{F} \\
62.2^{\circ} \mathrm{C}-76.7^{\circ} \mathrm{C}\end{array}$ & 9 & 8.5 \\
\hline Other & $\begin{array}{l}156.4^{\circ} \mathrm{F} \\
69.1^{\circ} \mathrm{C}\end{array}$ & $\begin{array}{c}115^{\circ} \mathrm{F}-180^{\circ} \mathrm{F} \\
46.1^{\circ} \mathrm{C}-82.2^{\circ} \mathrm{C}\end{array}$ & 37 & 16.5 \\
\hline
\end{tabular}

Our data suggest that written warnings have become prevalent and normative. The inclusion of written warnings on hot beverage cups and lids are so prevalent that such warnings can be considered an industry standard. The warnings, however, appear to have been applied with little consideration to the consumers' ability to notice and heed the warning. The warnings we encountered were often hard to see or spot. We cannot expect customers to attend to warnings that are not noticed! To increase the likelihood that the warnings are noticed, QSRs need to heed some of the warning design literature. Wogalter, Conzola and Smith-Jackson (2002), in their summary of research based guidelines for warning design, state that the first requirement of an effective warning is to be noticed, and that to be noticed the warnings need to be salient and conspicuous so that they catch the attention of consumers who may be focused on other tasks and activities. Specifically, they suggest that warning salience and conspicuity can be increased by the use of large bold print, high contrasts, colour, borders, pictorial symbols and special effects. They point out that an effective warning consists of four elements: (a) a signal word, such as 'DANGER, WARNING, CAUTION' and 'NOTICE' to catch attention, (b) identification of the hazard, (c) consequences of hazard exposure and (d) directives for avoiding 
the hazard. Pictorial symbols increase salience and memory and are particularly useful for those with deteriorating eyesight, such as the elderly, and those that cannot read or understand the message, such as children and the illiterate. Their discussion of personal factors, demographic variables, and habituation suggests that QSRs need to know their customers well in order to develop the most effective warning. McDonald's use of bilingual warning messages is a good example of attending to the particular needs of their customers.

Verbal warnings have decreased significantly. This is not consistent with responsible business practice. Food service operators know that hot beverages may indeed scald and harm their customers, and as such have a responsibility to warn them of the hazard. Adding a verbal warning is both cost-effective and prudent. Furthermore, verbal warnings provide added benefit as research suggests that auditory warnings, such as a verbal warning, penetrate a cluttered visual environment, draw attention to hazards, increase the sense of urgency, and leads to greater hazard avoidance (Wogalter et al., 2002). Drive-thru training should include a focus on customer protection and safety, incorporating a variety of appropriate verbal warnings.

It would be ideal if verbal warnings become as common as written warnings. Both verbal and written warnings should be standard in frequency, but varied in form to avoid warning habituation with subsequent decreased salience (Wogalter et al., 2002).

It is noteworthy that there has not been a general return to the pre-Liebeck service temperatures. The consistently higher service temperatures at Burger King suggest that they are not as focused on consumer wellbeing and safety as the other QSRs in this research. This does not bode well in terms of their potential liability should a Burger King customer suffer injury from their coffee. The consumer preference literature cited above suggests that it is not necessary to serve coffee at such high temperatures. 
We have consistently referred to the temperature of coffee at the time of service rather than during brewing or holding. It is at the point of service that the coffee temperature becomes a potential liability standard or at the very least a consumer hazard. Borchgrevink, Susskind and Tarras (1999) point out that the quality of coffee is a function of the amount of coffee solids that are extracted during brewing and that to obtain the ideal extraction the brewing temperature should typically fall within the $185^{\circ} \mathrm{F}\left(85^{\circ} \mathrm{C}\right)$ to $203^{\circ} \mathrm{F}\left(95^{\circ} \mathrm{C}\right)$ range. This would suggest that freshly brewed coffee will, by nature, be high in temperature. However, we need to point out that the brewing temperature argument is mostly an economic argument, as delicious coffee can be made at lower temperatures, but to obtain the desired extraction more coffee would have to be used in the brewing process, thus increasing the cost of each cup of coffee. 


\section{References}

Adams, A.S., \& Edworthy, J. (1995). Quantifying and predicting the effects of basic text display variables on the perceived urgency of warning labels: Tradeoffs involving font size, border weight and color. Ergonomics, 38(11), 2221-2237.

Borchgrevink, C.P., Susskind, A.M., \& Tarras, J.M. (1999). Consumer preferred hot beverage temperatures. Food Quality and Preference, 10(2), 117-121.

Cohen, J. (1988). Statistical Power Analysis for the behavioral Sciences (2nd ed.). Hillsdale, NJ: Lawrence Erlbaum Associates.

Edworthy, J., \& Adams, A. (1996). Warning design: A research prospective. London: Taylor Francis.

Gerlin, A. (1994, September Fleischer-Black, M. (2004, June 4). One lump or two? The American Lawyer. Retrieved October 25, 2006, from http://www.law.com/jsp/newswire_article.jsp?id=10856263490931). A matter of degree: How a jury decided that a coffee spill is Worth $\$ 2.9$ million. The Wall Street Journal, A1.

Greenbaum, J. (2005). McDonald's hot coffee lawsuit and beyond: The tort reform myth machine. Common Dreams News Center. Retrieved October 18, 2006, from http://www.commondreams.org/views05/0122_11.htm

Lane, J. (2006). The myth of the frivolous lawsuit. TortDeform: The Civil Justice Defense Blog. Retrieved October 24, 2006, from http://www. t o r t d e f o r m . c o m / a r c h i v e s / 2 $006 / 09 /$ the_myth_of_the_frivolous laws.html 
Lee, H.S., \& O’Mahoney, M. (2002). At what temperature do consumers like to drink coffee?: Mixing methods. Journal of Food Science, 67(7), 2774-2777.

Lee, H.S., Carstens, E., \& O’Mahoney, M. (2003). Drinking hot coffee: Why doesn't it burn the mouth? Journal of Sensory Studies,18(1), 19-32.

McGreevy, M. (1994). Hot coffee can get you into very hot water. Hospitality Law, 9(12), 9.

Mellen, P.F., Golle, Jr., M.F., \& Smialek, J.E. (1995). Fatal hot coffee scald of the larynx: Case report. The American Journal of Forensic Medicine and Pathology, 16(2), 117-119.

New York Times (January 3, 1995). A simple pleasure, made complicated. The New York Times, 144, C3.

Off the Kuff: Knowledge is good in the reality based community (2002). Lieback (sic) v. McDonald's. Retrieved October 18, 2006, from http://www.offthekuff.com/mt/archives/001070.html

Olson, W., \& Frank, T (2006) (Eds.) Justinian Lane: Reform Supporter. Overlawyered: Chronicling the high cost of our legal system. Retrieved October 24, 2006, from http://www.overlawyered.com/2006/09/justinian_lane_reform_supporte.html

Pipatsattayanuwong, S., Lee, H.S., Lau, S., \& O’Mahoney, M. (2001). Hedonic R-measurement of temperature preferences for drinking black coffee. Journal of Sensory Studies, 16(5), $517-536$.

Rutherford, D.G. (1998). Lessons from Liebeck. The Cornell Hotel and Restaurant Administration Quarterly, 39(3), 72-75.

Shaw, D. (1994, October 12). Coffee, tea or ouch? The New York Times, (p. C1). 
Silver, N.C., \& Braun, C.C. (1993). Perceived readability of warning labels with varied font sizes and styles. Safety Science, 16(5/6), 615-625.

StellaAwards.com pleading before the Court of Public Opinion. Stipulate the facts from the 'real' Stella's case. Retrieved October 23, 2006, from: http://www.stellaawards.com/stella.html

The real facts about the McDonald's coffee case. Retrieved October 18, 2006, from: http://www.hurt911.org/mcdonalds.html

Wogalter, M.S., Conzola, V.C., \& Smith-Jackson, T.L. (2002). Research-based guidelines for warning design and evaluation. Applied Ergonomics, 33, 219-230. 